
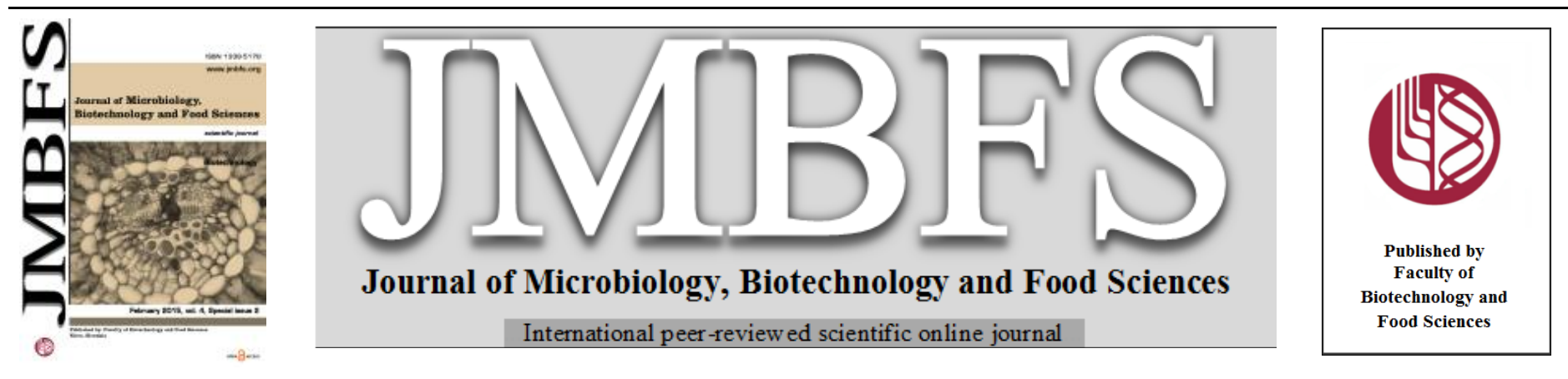

\title{
CURCUMIN IN MALE FERTILITY: EFFECTS ON SPERMATOZOA VITALITY AND OXIDATIVE BALANCE
}

\section{Eva Tvrdá*, Norbert Lukáč, Tomáš Jambor, Jana Lukáčová, Peter Massányi}

Address(es): MSc. Eva Tvrdá, PhD.

Slovak University of Agriculture in Nitra, Faculty of Biotechnology and Food Sciences, Department of Animal Physiology, Tr. A. Hlinku 2, 94976 Nitra, +421 37641 4288.

*Corresponding author: evina.tvrda@gmail.com

doi: 10.15414/jmbfs.2015.4.special2.120-124

\section{ARTICLE INFO}

Received 2. 10. 2014

Revised 16. 10. 2014

Accepted 19. 11. 2014

Published 2. 2. 2015

\section{Regular article}

OPEN $\partial_{\text {ACCESS }}$

\begin{abstract}
The aim of this study was to assess the dose- and time-dependent effects of curcumin on bovine spermatozoa during short-term ( $0 \mathrm{~h}, 2 \mathrm{~h}$, $6 \mathrm{~h})$ and long-term $(12 \mathrm{~h}, 24 \mathrm{~h})$ in vitro culture periods. Semen samples were collected from 20 adult breeding bulls, and diluted in physiological saline solution containing $0.5 \%$ DMSO together with $0,1,5,10,50$ and $100 \mu \mathrm{M} / \mathrm{L}$ of curcumin. Spermatozoa motion parameters were determined using the SpermVision ${ }^{\mathrm{TM}}$ and CASA (Computer Assisted Semen Analyzer) system. Cell viability was measured using the metabolic activity MTT assay, and the nitroblue-tetrazolium (NBT) test was used to assess the intracellular superoxide formation. The CASA analysis revealed that concentrations of $50 \mu \mathrm{M} / \mathrm{L}$ and $10 \mu \mathrm{M} / \mathrm{L}$ of curcumin were able to significantly prevent the decrease of motility and progressive motility ( $\mathrm{P}<0.001$ in case of group $\mathrm{B}$ and $\mathrm{P}<0.01$ in case of group $\mathrm{C}$ ) over all time periods of the in vitro incubation. At the same time, supplementation of concentrations ranging from $50 \mu \mathrm{M} / \mathrm{L}$ to $5 \mu \mathrm{M} / \mathrm{L}$ of curcumin led to a significant preservation of the cell viability in comparison to the control $(\mathrm{P}<0.001$ in case of groups $\mathrm{B}$ and $\mathrm{C} ; \mathrm{P}<0.05$ in case of group D). Concentrations in between $50 \mu \mathrm{M} / \mathrm{L}$ and $5 \mu \mathrm{M} / \mathrm{L}$ of curcumin demonstrated antioxidant properties, translated in a significant reduction of the intracellular superoxide production throughout the in vitro culture $(\mathrm{P}<0.001)$. The results indicate that the addition of curcumin, especially in concentrations between $50 \mu \mathrm{M}$ and $10 \mu \mathrm{M}$ to the culture medium could be beneficial for a complex enhancement of spermatozoa activity and protection against complications resulting from in vitro culture.
\end{abstract}

Keywords: Curcumin, spermatozoa, bulls, motility, viability, oxidative stress

\section{INTRODUCTION}

Over the last years, different studies have evaluated the beneficial effects of oral antioxidant administration on spermatozoa physiology and fertility in animals and humans (Donnely et al., 1999; Agarwal and Sekhon, 2010). However, data regarding the in vitro effects of antioxidants on the sperm cell is still very sparse or controversial. The in vitro data are however essential, as it has been systematically shown that diverse antioxidants may protect the male germ cells against oxidative injury and subsequent sperm dysfunction (i.e. loss of motility and viability). This is essential for spermatozoa processing protocols routinely performed in medical and veterinary laboratories for long-term spermatozoa preservation (cryoconservation) or procedures related to assisted reproductive techniques. The in vitro environment represents an additional danger to the sperm survival, as it provides suitable conditions for ROS (reactive oxygen species) overproduction and a subsequent structural and/or functional damage to the sperm cell (Saleh and Agarwal, 2002).

The addition of synthetic antioxidants to cell cultures is one of the most efficient ways to prevent oxidative damage. However, the safety of synthetic additives has been questioned stimulating the evaluation of naturally occurring compounds with antioxidant properties. Moreover, the chemical diversity, structural complexity, availability, lack of significant toxic effects and intrinsic biologic activity of natural products make them ideal candidates for new therapeutics (Alarcón de la Rastra, 2008).

The polyphenol curcumin [1,7-bis(4-hydroxy-3-methoxyphenyl)-1,6-heptadiene3,5-dione] (CUR) is a major bioactive chemical component of turmeric power, found in the herbal remedy and dietary spice turmeric. This vibrant yellow spice is derived from the rhizome of the plant Curcuma longa Linn which is obtained by crushing the roots into powder (Ammon and Wahl, 1991; Litwinienko and Ingold, 2004). Curcumin is the phytochemical that gives a yellow color to turmeric and is now recognized as being responsible for most of its therapeutic effects (Aggarwal et al., 2007).

Curcumin with its proven antioxidant properties has been shown to have several therapeutic advantages. It was shown to be a potent scavenger of a variety of reactive oxygen species including superoxide anion radicals, hydroxyl radicals (Reddy and Lokesh, 1994) as well as nitrogen dioxide radicals (Unnikrishnan and Rao, 1995; Sreejayan and Rao, 1997). It was also shown to inhibit lipid peroxidation in different animal models (Reddy and Lokesh, 1992; Sreejayan and Rao, 1994).

Controversial data are however available with respect to the effects of CUR on male fertility parameters. Several in vivo (Salahshoor et al., 2012) as well as in vitro studies (Bucak et al., 2012; Hendin et al., 2013) strongly emphasize on the involvement of CUR in energy-promoting and protective effects of CUR on the testicular tissue, spermatogenesis as well as oxidative balance of the sperm cell. Furthermore, CUR has been shown to reverse male toxicity caused by a variety of physiological (Wei et al., 2009) or environmental factors (El-Wakf et al., 2011; Dev et al., 2013; Khorsandi et al., 2013). At the same time, other studies implicate the negative involvement of CUR in pathways related to human and murine spermatogenesis (Naz, 2011; Xia et al., 2012) suggesting a cautious and thorough investigation of CUR toxicity as well as contraceptive effects.

The present in vitro study is therefore aimed to find out the efficacy of CUR on bovine spermatozoa motility, viability and superoxide radical formation during a 24 hour in vitro cultivation, in order to define an optimal concentration of this compound for further experiments.

\section{MATERIAL AND METHODS}

Bovine semen samples were obtained from 20 adult breeding bulls (Slovak Biological Services, Nitra, Slovak Republic). The samples had to accomplish the basic criteria given for the corresponding breed. The samples were obtained on a regular collection schedule using an artificial vagina. After collecting the samples were stored in the laboratory at room temperature $\left(22-25^{\circ} \mathrm{C}\right)$.

Each sample was diluted in physiological saline solution (PS; sodium chloride $0.9 \%$ w/v; Bieffe Medital, Italia) containing 0.5\% DMSO (Dimethyl sulfoxide; Sigma-Aldrich, St. Louis, USA), with various concentrations of CUR (SigmaAldrich, St. Louis, USA; A - 100; B $-50 ; \mathrm{C}-10 ; \mathrm{D}-5 ; \mathrm{E}-1 \mu \mathrm{M} / \mathrm{L}$ ) using a dilution ratio of $1: 40$. The samples were cultured at room temperature $\left(22-25^{\circ} \mathrm{C}\right)$. We compared the control (Ctrl) group (medium without CUR supplementation) with the experimental groups.

Motility and progressive motility analysis was carried out using the CASA (Computer Assisted Semen Analyzer) system equipped with the SpermVision ${ }^{\mathrm{TM}}$ program (MiniTub, Tiefenbach, Germany) and the Olympus BX 51 microscope (Olympus, Japan) at cultivation Times $0 \mathrm{~h}, 2 \mathrm{~h}, 6 \mathrm{~h}$ (models suitable for a shortterm in vitro culture) as well as $12 \mathrm{~h}$ and $24 \mathrm{~h}$ (models suitable for a long-term in 
vitro culture). Each sample was placed into the Makler Counting Chamber (depth $10 \mu \mathrm{m}$, Sefi-Medical Instruments, Israel) and the percentage of motile (motility $>5 \mu \mathrm{m} / \mathrm{s}$; MOT) and progressively motile spermatozoa (motility $>20$ $\mu \mathrm{m} / \mathrm{s}$; PROG) was evaluated. 1000-1500 cells were assessed in each analysis (Massányi et al., 2008). Viability of the cells exposed to CUR in vitro was evaluated by the metabolic activity (MTT) assay (Mosmann, 1983; Knazicka $\boldsymbol{e}$ al., 2012). This colorimetric assay measures the conversion of 3-(4,5dimetylthiazol-2-yl)-2,5- diphenyltetrazolium bromide (MTT; Sigma-Aldrich, St Louis, USA) to purple formazan particles by mitochondrial succinate dehydrogenase of intact mitochondria of living cells. Formazan can then be measured spectrophotometrically at a measuring wavelength of $570 \mathrm{~nm}$ against $620 \mathrm{~nm}$ as reference by a microplate ELISA reader (Multiskan FC, ThermoFishe Scientific, Finland). The data are expressed in percentage of control (i.e. optical density of formazan from cells not exposed to CUR). Results from the analysis were collected during five repeated experiments at each concentration.

The nitroblue-tetrazolium (NBT) test was used to assess the intracellular formation of superoxide radical (Esfandiari et al., 2003). This assay is conducted by counting the cells containing blue NBT formazan deposits, which are formed by reduction of the membrane permeable, water-soluble, yellow-colored nitroblue tetrazolium chloride (2,2'-bis(4-Nitrophenyl)-5, 5'-diphenyl-3,3'-(3,3'dimethoxy-4,4'-diphenylene)ditetrazolium chloride; Sigma-Aldrich, St. Louis USA) and superoxide radical. Formazan can be measured spectrophotometrically at a measuring wavelength of $620 \mathrm{~nm}$ against $570 \mathrm{~nm}$ as reference by a microplate ELISA reader (Multiskan FC, ThermoFisher Scientific, Finland). The data were expressed in percentage of control (i.e. optical density of formazan from cells not exposed to CUR). Results from the analysis were collected during five repeated experiments at each concentration (Tvrdá et al., 2013).

Statistical analysis was carried out using the GraphPad Prism program (version 3.02 for Windows; GraphPad Software, La Jolla California USA, www.graphpad.com). Descriptive statistical characteristics (mean, standard error) were evaluated at first. One-way ANOVA with Dunnett's post test was used for statistical evaluations. The level of significance was set at ${ }^{* * *}(\mathrm{P}<0.001) ; *$ $(\mathrm{P}<0.01) ; *(\mathrm{P}<0.05)$

\section{RESULTS AND DISCUSSION}

The CASA assessment of the motion parameters showed a gradual decrease of spermatozoa motility and progressive motility in all groups over the course of a $24 \mathrm{~h}$ in vitro culture (Table 1, Table 2). The initial (Time 0h) MOT was higher in all experimental groups when compared to the control group $(0 \mu \mathrm{M} / \mathrm{L}$ CUR) although without any statistical significance $(\mathrm{P}>0.05)$. Although statistically insignificant, a motion-promoting effect of CUR remained visible after $2 \mathrm{~h}$, specifically in experimental groups B $(50 \mu \mathrm{M} / \mathrm{L}$ CUR $), C(10 \mu \mathrm{M} / \mathrm{L}$ CUR $)$ and $\mathrm{D}$ $(5 \mu \mathrm{M} / \mathrm{L}$ CUR). At the same time, $100 \mu \mathrm{M} / \mathrm{L}$ CUR (group A) caused a nonsignificant decrease of the spermatozoa motility parameters. After $6 \mathrm{~h}$, the decline of spermatozoa motion characteristics was significantly ceased in the group B $(\mathrm{P}<0.001$ in case of MOT and $\mathrm{P}<0.05$ in case of $\mathrm{PROG})$ in comparison with the control. Examination at $12 \mathrm{~h}$ of in vitro culture showed that the spermatozoa motility and progressive motility were significantly increased in groups B $(\mathrm{P}<0.001)$ and $\mathrm{C}(\mathrm{P}<0.05)$ when compared to the control. At the same time, an insignificantly higher $(\mathrm{P}>0.05)$ motion parameters were recorded in the group $\mathrm{D}$, while a non-significant $(\mathrm{P}>0.05)$ decline was observed in groups $\mathrm{A}$ and $\mathrm{E}(1$ $\mu \mathrm{M} / \mathrm{L}$ CUR) in a comparison with the control group. At the end of the experiments $(24 \mathrm{~h})$, the highest motility parameters were observed in the experimental groups $\mathrm{B}$ and $\mathrm{C}$, being significantly higher in comparison with the control $(\mathrm{P}<0.001$ in case of $\mathrm{B}$ and $\mathrm{P}<0.01$ in case of $\mathrm{C})$. Meanwhile, both MOT as well as PROG were significantly decreased $(\mathrm{P}<0.05)$ in the group $\mathrm{A}$ supplemented by the highest concentration of CUR, after a comparison with the Ctrl group (Table 1, Table 2).

Table 1 Spermatozoa motility (\%) in the absence (Ctrl) or presence (A-E) of curcumin during different time periods (Mean \pm SEM; $n=20$ )

\begin{tabular}{|c|c|c|c|c|c|c|}
\hline Groups & Ctrl & $\overline{\mathbf{A}}$ & $\bar{B}$ & $\mathbf{C}$ & D & $\mathbf{E}$ \\
\hline \multicolumn{7}{|l|}{ Time 0h } \\
\hline & $87.36 \pm 1.16$ & $90.08 \pm 1.27$ & $92.41 \pm 1.30$ & $88.17 \pm 0.88$ & $89.13 \pm 1.27$ & $87.50 \pm 0.96$ \\
\hline \multicolumn{7}{|l|}{ Time 2 h } \\
\hline & $84.02 \pm 1.72$ & $81.55 \pm 2.29$ & $89.73 \pm 1.70$ & $87.38 \pm 1.67$ & $86.31 \pm 1.32$ & $84.04 \pm 1.10$ \\
\hline \multicolumn{7}{|l|}{ Time $6 \mathrm{~h}$} \\
\hline & $75.99 \pm 3.51$ & $70.28 \pm 2.09$ & $86.68 \pm 1.57^{* * * \pi}$ & $80.84 \pm 1.68$ & $77.21 \pm 1.98$ & $75.92 \pm 1.54$ \\
\hline \multicolumn{7}{|l|}{ Time $12 \mathrm{~h}$} \\
\hline & $71.47 \pm 1.87$ & $65.79 \pm 1.12$ & $83.82 \pm 1.03^{* * * F}$ & $76.93 \pm 2.04^{*}$ & $73.30 \pm 1.87$ & $69.48 \pm 2.91$ \\
\hline \multicolumn{7}{|l|}{ Time $24 \mathrm{~h}$} \\
\hline & $52.41 \pm 2.67$ & $44.12 \pm 1.41^{*}$ & $62.75 \pm 2.74^{* * *}$ & $60.10 \pm 3.02^{* *}$ & $57.20 \pm 3.06$ & $54.42 \pm 2.75$ \\
\hline
\end{tabular}

Table 2 Spermatozoa progressive motility $(\%)$ in the absence (Ctrl) or presence (A-E) of curcumin during different time periods (Mean \pm SEM; $n=20$ )

\begin{tabular}{|c|c|c|c|c|c|c|}
\hline Groups & Ctrl & $\mathbf{A}$ & B & $\mathrm{C}$ & D & $\mathbf{E}$ \\
\hline \multicolumn{7}{|l|}{ Time $0 \mathrm{~h}$} \\
\hline & $78.79 \pm 1.38$ & $82.51 \pm 1.38$ & $82.87 \pm 1.25$ & $76.50 \pm 1.44$ & $75.62 \pm 1.45$ & $74.19 \pm 1.61$ \\
\hline \multicolumn{7}{|l|}{ Time 2 h } \\
\hline & $77.08 \pm 1.74$ & $79.44 \pm 3.47$ & $78.97 \pm 1.73$ & $75.50 \pm 1.58$ & $73.70 \pm 1.41$ & $73.62 \pm 1.25$ \\
\hline \multicolumn{7}{|l|}{ Time $6 \mathrm{~h}$} \\
\hline & $69.06 \pm 3.44$ & $67.67 \pm 2.13$ & $73.37 \pm 1.62^{*}$ & $72.11 \pm 1.64$ & $72.10 \pm 1.93$ & $67.24 \pm 1.52$ \\
\hline \multicolumn{7}{|l|}{ Time $12 \mathrm{~h}$} \\
\hline & $61.84 \pm 1.76$ & $58.98 \pm 1.95$ & $71.94 \pm 1.12^{* * *}$ & $67.03 \pm 2.08^{*}$ & $64.02 \pm 1.72$ & $60.14 \pm 3.06$ \\
\hline \multicolumn{7}{|l|}{ Time $24 \mathrm{~h}$} \\
\hline & $44.79 \pm 2.69$ & $37.73 \pm 3.11^{*}$ & $56.10 \pm 2.80^{* * * *}$ & $51.14 \pm 2.97^{* 2}$ & $45.73 \pm 1.71$ & $44.98 \pm 2.94$ \\
\hline
\end{tabular}

According to the MTT assay, the immediate CUR administration (Time 0h) had no significant effects on the sperm cell viability in any of the experimental groups (P>0.05; Figure 1). At $2 \mathrm{~h}$ it was revealed that $50 \mu \mathrm{M} / \mathrm{L}$ CUR (group B), $10 \mu \mathrm{M} / \mathrm{L}$ CUR (group C) as well as $5 \mu \mathrm{M} / \mathrm{L}$ CUR (group D) had a stimulating and vitality-promoting effect on the bovine spermatozoon, alongside with statistically significant results $(\mathrm{P}<0.001$ in case of groups $\mathrm{B}$ and $\mathrm{C} ; \mathrm{P}<0.05$ in case of group D) when compared to the control group $(0 \mu \mathrm{M} / \mathrm{L}$ CUR; Figure 2). These beneficial effects remained visible and statistically relevant throughout the entire in vitro culture, as shown in Figure 3 (Time $6 \mathrm{~h} ; \mathrm{P}<0.001$ in groups $\mathrm{B}, \mathrm{C}$ and D), Figure 4 (Time $12 \mathrm{~h} ; \mathrm{P}<0.001$ in case of groups B and C; $\mathrm{P}<0.05$ in case of group D) as well as Figure 5 (Time $24 \mathrm{~h} ; \mathrm{P}<0.001$ in case of groups B and C; $\mathrm{P}<0.05$ in case of group D). Similar to the CASA analysis, the MTT test revealed an inhibition in the cell viability followed by the administration of $100 \mu \mathrm{M} / \mathrm{L}$ CUR (group A), however the differences were non-significant at full length of the in vitro spermatozoa culture $(\mathrm{P}<0.05$; Figures $1-5)$. Moreover it was shown that the administration of $1 \mu \mathrm{M} / \mathrm{L}$ CUR (group E) had no specific effects on the spermatozoa survival during the entire experiment $(\mathrm{P}<0.05$; Figures $1-5)$. 

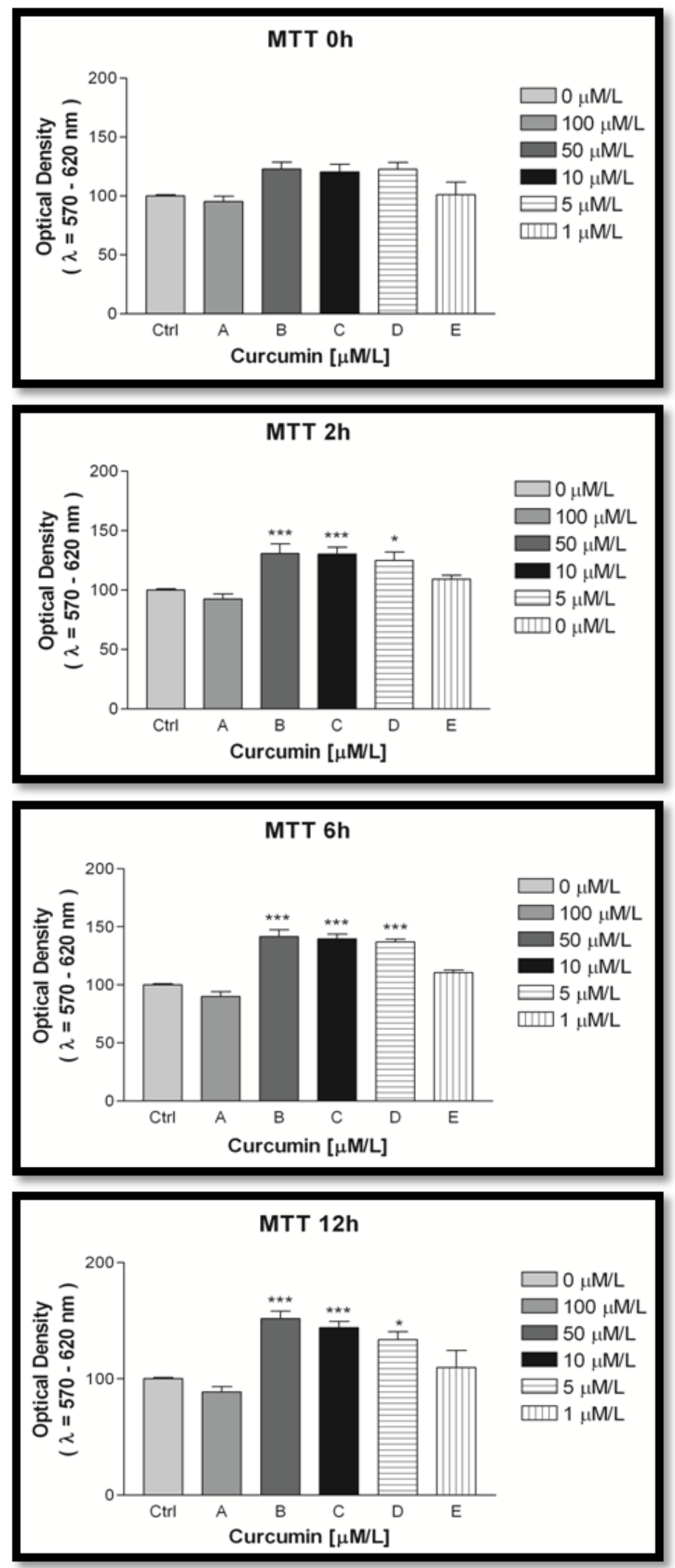

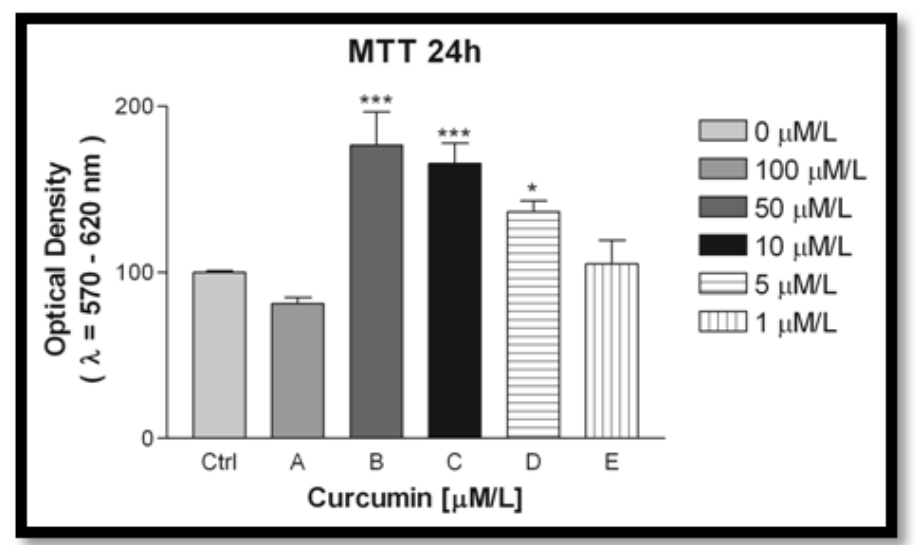

Figures 1, 2, 3, 4, 5 The effect of various doses of curcumin on the viability of bovine spermatozoa at $0 \mathrm{~h}, 2 \mathrm{~h}, 6 \mathrm{~h}, 12 \mathrm{~h}$ and $24 \mathrm{~h}$.

Each bar represents mean $( \pm$ SEM $)$ optical density as the percentage of controls $(n=20)$, which symbolize $100 \%$. The data were obtained from five independent

experiments. The level of significance was set at ${ }^{* * *} \mathrm{P}<0.001 ;{ }^{* * *} \mathrm{P}<0.01 ;{ }^{*} \mathrm{P}<0.05$.

Although CUR had no instant effects on the oxidative balance within the in vitro spermatozoa culture ( $P>0.05$; Figure 6$)$, experiments following a $2 \mathrm{~h}$ cultivation revealed that administration of $50 \mu \mathrm{M}$ CUR led to a significant decline of the superoxide formation in comparison to the Control $(0 \mu \mathrm{M}$ CUR; Figure 7$)$. Starting with Time $6 \mathrm{~h}$ and following the entire in vitro incubation it was shown that CUR concentrations ranging from $50 \mu \mathrm{M}$ to $5 \mu \mathrm{M}$ (groups $\mathrm{B}, \mathrm{C}$ and $\mathrm{D}$ ) exhibited a long-term and statistically significant $(\mathrm{P}<0.001)$ antioxidant protection of the male germ cells and a subsequent prevention of the escalating intracellular superoxide production, considered to be the first step in the creation of oxidative stress (Figures 7, 8,9 and 10). On the other hand, high (group A) as well as very low (group E) concentrations of CUR had no significant effects $(\mathrm{P}>0.05)$ on the superoxide generation within the spermatozoon neither during short-term (Figures 6,7 and 8) nor during long-term timeframes (Figures 9 and 10) of the in vitro culture.
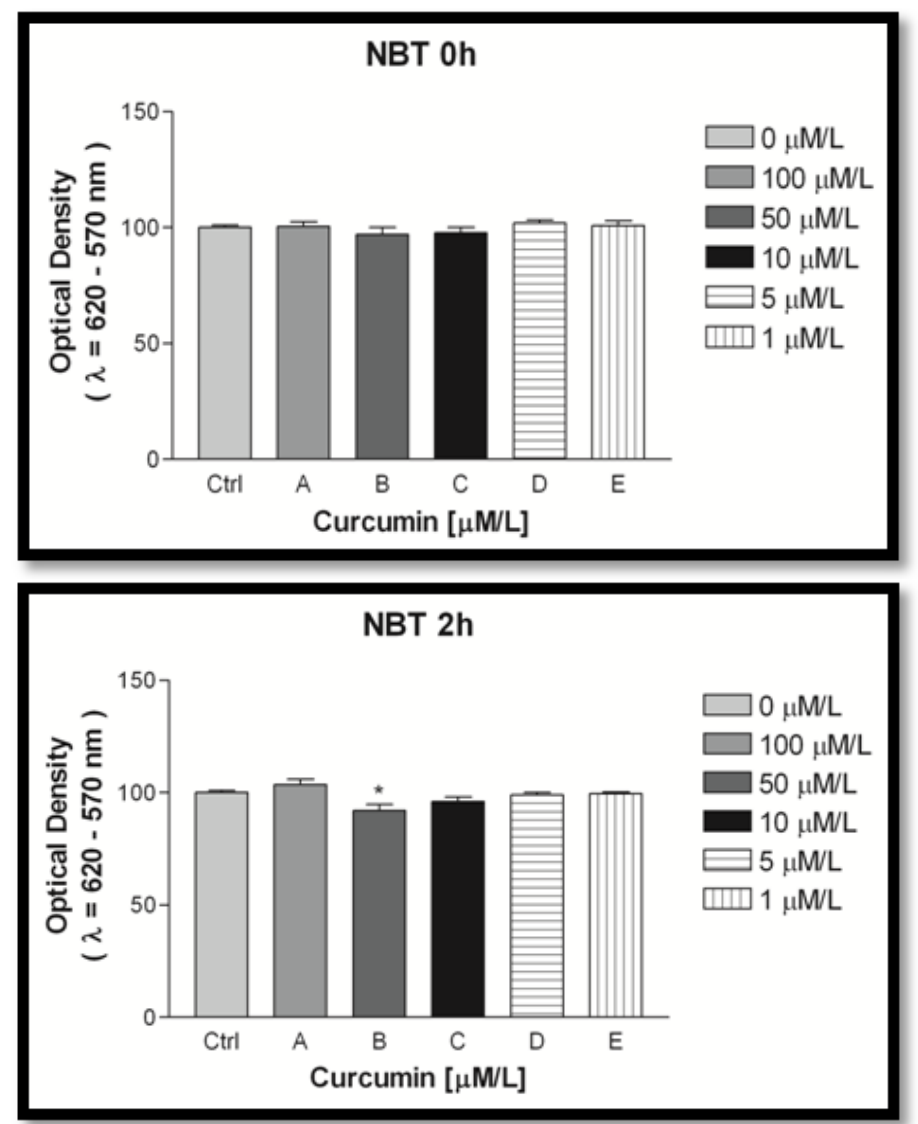

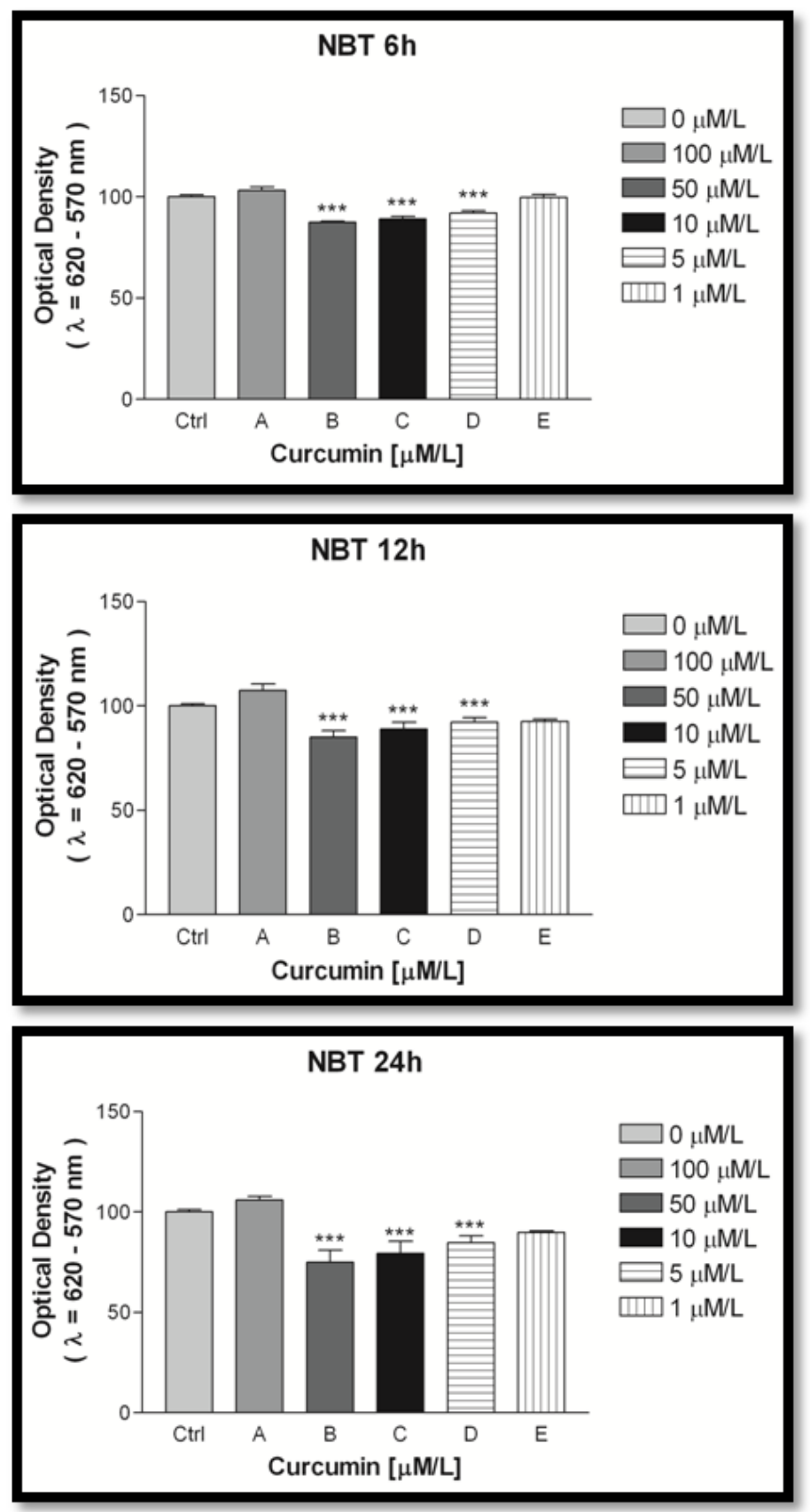

Figures $6,7,8,9,10$ The effect of various doses of curcumin on the spermatozoa superoxide production at $0 \mathrm{~h}, 2 \mathrm{~h}, 6 \mathrm{~h} 12 \mathrm{~h}$ and $24 \mathrm{~h}$.

Each bar represents the mean $( \pm$ SEM) optical density as the percentage of controls $(n=20)$, which symbolize $100 \%$. The data were obtained from five independent experiments. The level of significance was set at ${ }^{* * *} \mathrm{P}<0.001 ;{ }^{* *} \mathrm{P}<0.01 ;{ }^{*} \mathrm{P}<0.05$.

Past data available on the impact of CUR on male fertilization potential are controversial. In a study by Salashoor et al. (2012), increasing doses of CUR significantly increased reproductive indices such as sperm concentration, motility and testosterone content in rats. Inversely, Naz (2011) showed that incubation of human or murine sperm with CUR caused a concentration-dependent decrease in sperm forward motility, capacitation and acrosome reaction. At high CUR concentrations, there was a complete block of spermatozoa motility and function. Our results agree with Salashoor et al. (2012) and suggest stimulating and protective effects of CUR on spermatozoa motility and antioxidant status.

The first report on the useful effects of curcumin (Bucak et al., 2008) on postthawed sperm quality (motility and morphology) and antioxidant activities of cooled ram spermatozoa has given rise to its use as an antioxidant additive and has been shown to have cryoprotective effects when added to the freezing extender. Motility parameters recorded by our CASA system are in accordance with previous findings by Bucak et al. (2008; 2010) demonstrating a marked improvement in the motion of post-thawed ram spermatozoa supplemented with the curcumin. Inversely, their later study based on the CUR supplementation to the cryopreservation medium for bovine semen led to nonsignificant differences in the sperm motion characteristics (Bucak et al., 2012). The spermatozoon motility and viability generally declines during in vitro incubation. We observed a gradual decrease in viability and motility copied by an increase in superoxide production resulting in low conception rate and a low success in ART techniques, as seen by Soleimanzadeh and Saberivand (2013) as well as Marcus-Braun et al. (2004). Our results correlate with the report by Soleimanzadeh and Saberivand (2013) in frozen-thawed semen, where CUR addition had a positive impact on both motility and viability.

One of the possible ameliorative mechanisms of curcumin on the above mentioned parameters is to scavenge the free radicals and thereby act as an antioxidant. Another reason for the enhancement of sperm motility in spermatozoa observed in this study may be due to the increasing levels ROSscavenging molecules, being in accordance with total antioxidant level of semen in curcumin supplemented group by by Soleimanzadeh and Saberivand (2013). The antioxidant capacity of sperm is closely related to male fertility, as an appropriate antioxidant status provides a favorable environment for sperm swimming. The decreased level of antioxidants in the sample may be one of the causes of male infertility (Agarwal et al., 2003). Semen processing, cryopreservation and induction of OS may decrease the antioxidant defense capacity of semen. Based on our results, the addition of curcumin to fresh sperm of bulls significantly preserved the antioxidant defense mechanisms in the sperm cells, agreeing with the conclusions drawn by Soleimanzadeh and Saberivand (2013). Furthermore, a significant preservation of DNA integrity and post-thaw motility in curcumin supplemented group of rats compared to the control, was most probably due to increase in its antioxidant capacity, as Soleimanzadeh and Saberivand (2013) conclude.

\section{CONCLUSION}

In the present study, in vitro-mediated damage to sperm cell with a subsequent loss of spermatozoa fertilizing potential could be reduced using various doses of curcumin. We may conclude that all doses of curcumin increase the percentage of motile and viable spermatozoa but decreased and prevented the intracellular overproduction of free radicals within the sperm mitochondrial membrane. The most effective concentrations of curcumin seem to vary between 50 and 10 $\mu \mathrm{M} / \mathrm{L}$, although it may be important to further investigate specific doeses of curcumin specifically within the selected range.

According to our results, curcumin seems to protect bovine spermatozoa agains the damage caused by the hostile in vitro environment. Supplementing the semen samples with curcumin could therefore be of scientific importance for extending the time of spermatozoa processing and storage before further designated andrology experiments and clinical procedures, such as artificial insemination, cryopreservation or in vitro fertilization techniques.

Acknowledgments: This work was co-funded by the European Community under the Project no. 26220220180: Building Research Centre „AgroBioTech” and the Scientific Grant Agency of the Ministry of Education of the Slovak Republic and of the Slovak Academy of Sciences VEGA Project no. 1/0857/14.

\section{REFERENCES}

AGARWAL, A., SALEH, R.A., BEDAIWY, M.A. 2003. Role of reactive oxygen species in the pathophysiology of human reproduction. Fertility and Sterility, 79(4), 829-843. http://dx.doi.org/10.1016/S0015-0282(02)04948-8.

AGARWAL, A., SEKHON, L. 2010. The role of antioxidant therapy in the treatment of male infertility. Human Fertility, 13(4), 217-225 http://dx.doi.org/10.3109/14647273.2010.532279.

AGGARWAL, B.B., SUNDARAM, C., MALANI, N., ICHIKAWA, H. 2007. Curcumin: the Indian solid gold. Advances in Experimental Medicine and Biology, 595, 1-75. http://dx.doi.org/10.1007/978-0-387-46401-5_1.

ALARCÓN DE LA RASTRA, C. 2008. Curcumin: a promising spice for therapeutics. Molecular Nutrition \& Food Research, 52, 985. http://dx.doi.org/10.1002/mnfr.200890036.

AMMON, H., WAHL, M.A. 1991. Pharmacology of Curcuma longa. Planta Medica, 57, 1-7. http://dx.doi.org/10.1055/s-2006-960004.

BUCAK, M.N., ATESSAHIN, A., YUCE, A. 2008. Effect of anti-oxidants and oxidative stress parameters on ram semen after the freeze-thawing process. Small Ruminant Research, 75, 128-134 http://dx.doi.org/10.1016/j.cryobiol.2010.09.001.

BUCAK, M.N., SARIOZKAN, S., TUNCER, P.B., SAKIN, F., ATESSAHIN, A., KULAKSIZ, R., CEVIK, M. 2010. The effect of antioxidants on post-thawed Angora goat (Capra hircus ancryrensis) sperm parameters, lipid peroxidation and antioxidant activities. Small Ruminant Research, 89, 24-30. http://dx.doi.org/10.1016/j.smallrumres.2009.11.015.

BUCAK, M.N., BASSPINAR, N., TUNCER, B.P., COYAN, K., SARIOZKAN, S., AKALIN, P.P., BUYUKLEBLEBICI, S., KUCUKGUNAY, S. 2012. Effects of curcumin and dithioerythritol on frozen-thawed bovine semen. Andrologia, 44, 102-109. http://dx.doi.org/10.1111/j.1439-0272.2010.01146.x. 
DEV, K.R., YADAMMA, K., REDDY, K.D. 2013. Protective effects of curcumin in cyclophosmphamide induced sperm head abnormalities in male mice. International Journal of Pharma and Bio Sciences, 4(1), 1131-1137.

DONNELLY, E.T., MCCLURE, N., LEWIS, S.E.M. 1999. The effect of ascorbate and $\alpha$-tocopherol supplementation in vitro on DNA integrity and hydrogen peroxide-induced DNA damage in human spermatozoa. Mutagenesis, 14(5), 505-512. http://dx.doi.org/10.1093/mutage/14.5.505.

EL-WAKF, A., ELHABIBY, E.S.M., EL-KHOLY, W.M., EL-GHANY, E.A.E 2011. Use of tumeric and curcumin to alleviate adverse reproductive outcomes of water nitrate pollution in male rats. Nature and Science, 9(7), 229-239.

ESFANDIARI, N., SHARMA, R.K., SHARMA, R.K., SALEH, R.S., THOMAS Jr., A.J., AGARWAL, A. 2003. Utility of the nitroblue tetrazolium reduction test for assessment of reactive oxygen species production by seminal leukocytes and

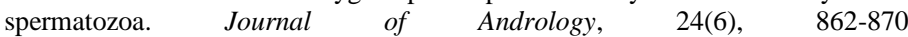
http://dx.doi.org/10.1002/j.1939-4640.2003.tb03137.x.

HENDIN, B.N., KOLETTIS, P.N., SHARMA, R.K., THOMAS, A.J. Jr., SOLEIMANZADEH, A., SABERIVAND, A. 2013. Effect of curcumin on rat sperm morphology after the freeze-thawing process. Veterinary Research Forum, 4(3), 185-189.

KHORSANDI, L., MIRHOSEINI, M., MOHAMADPOUR, M., ORAZIZADEH, M., KHAGHANI, S. 2013. Effect of curcumin on dexamethasone-induced testicular toxicity in mice. Pharmaceutical Biology, 51(2), 206-212. http://dx.doi.org/10.3109/13880209.2012.716854.

KNAZICKA, Z., TVRDA, E., BARDOS, L., LUKAC, N. 2012. Dose- and timedependent effect of copper ions on the viability of bull spermatozoa in different media. In Journal of Environmental Science and Health Part A, 47, 1294-1300. http://dx.doi.org/10.1080/10934529.2012.672135.

LITWINIENKO, G., INGOLD, K. 2004. Abnormal solvent effects on hydrogen atom abstraction. 2. Resolution of the curcumin antioxidant controversy. The role of sequential proton loss electron transfer. The Journal of Organic Chemistry, 69(18), 5888-5896. http://dx.doi.org/10.1021/jo049254j.

MARCUS-BRAUN, N., BRAUN, G., POTASHNIK, G. 2004. Effect of cryopreservation on quality and fertilization capacity of human sperm. European Journal of Obstetrics \& Gynecology and Reproductive Biology, 116, 63-66. http://dx.doi.org/10.1016/j.ejogrb.2004.01.036.

MASSANYI, P., CHRENEK, N., LUKÁČ, N., MAKAREVICH, A.V., OSTRO, A., ŽIVČAK, J., BULLA, J. 2008. Comparison of different evaluation chamber for analysis of rabbit spermatozoa motility using CASA system. Slovak Journal of Animal Science, 41, 2008, 60-66.

MOSMANN, T. 1983. Rapid colorimetric assay for cellular growth and surrival: application to proliferation and cytotoxicity assays. Journal of Immunological Methods, 65, 55-63. http://dx.doi.org/10.1016/0022-1759(83)90303-4.

NAZ, R.J. 2011. Can curcumin provide an ideal contraceptive? Molecular Reproduction and Development, 78, 116-123. http://dx.doi.org/10.1002/mrd.21276.

REDDY, A.C., LOKESH, B.R. 1992. Studies on spice principles as antioxidants in the inhibition of lipid peroxidation of rat liver microsomes. Molecular and Cellular Biochemistry, 111(1-2), 117-124. http://dx.doi.org/10.1007/BF00229582.

REDDY, A.C. LOKESH, B.R. 1994. Studies on the inhibitory effects of curcumin and eugenol on the formation of reactive oxygen species and the oxidation of ferrous iron. Molecular and Cellular Biochemistry, 137(1), 1-8. http://dx.doi.org/10.1007/BF00926033.

SALAHSHOOR, M.R., JALILI, C., KHAZAEI, M., KHANI, F. 2012. Effects of curcumin on reproductive parameters in male mice. Journal of Clinical Research in Paramedical Sciences, 1(3), 1-3.

SALEH, R.A., AGARWAL, A. 2002. Oxidative stress and male infertility: from research bench to clinical practice. Journal of Andrology, 23(6), 737-752.

SOLEIMANZADEH, A., SABERIVAND, A. 2013. Effect of curcumin on ra sperm morphology after the freeze-thawing process. Veterinary Research Forum, 4(3), 185-189. http://dx.doi.org/10.1016/S0093-691X(02)01231-1.

SREEJAYAN, J.D., RAO, M.N. 1994. Curcuminoids as potent inhibitors of lipid peroxidation. Journal of Pharmacy and Pharmacology, 46(12), 1013-1016. http://dx.doi.org/10.1111/j.2042-7158.1994.tb03258.x

SREEJAYAN, J.D., RAO, M.N. 1997. Nitric oxide scavenging by curcuminoids Journal of Pharmacy and Pharmacology, 49, 105-107. http://dx.doi.org/10.1111/j.2042-7158.1997.tb06761.x.

TVRDÁ, E., LUKÁČ, N., LUKÁČOVÁ, J., KŇAŽICKÁ, Z., MASSÁNYI, P. 2013. Stimulating and protective effects of vitamin $E$ on bovine spermatozoa Journal of Microbiology, Biotechnology and Food Sciences, 2(1), 1386-1395.

UNNIKRISHNAN, M.K., RAO, M.N. 1995. Curcumin inhibits nitrogen dioxide induced oxidation of hemoglobin. Molecular and Cellular Biochemistry, 146(1), 35-37. http://dx.doi.org/10.1007/BF00926878.

WEI, S.M., YAN, Z.Z., ZHOU, J. 2009. Curcumin attenuates ischemiareperfusion injury in rat testis. Fertility and Sterility, 91, 271-277. http://dx.doi.org/10.1016/j.fertnstert.2007.10.082.

XIA, X., CAI, H., QIN, S., XU, CH. 2012. Histone acetylase inhibitor curcumin impairs mouse spermiogenesis - an in vitro study. PLoS ONE, 7(11), e48673 111. http://dx.doi.org/10.1371/journal.pone.0048673.
PAETKAU, D., CALVERT, W., STIRLING, I., STROBECK, C. 1995 Microsatellite analysis of population structure in Canadian polar bears. Mol. Ecol., 4, 347-354. http://dx.doi.org/10.1111/j.1365-294x.1995.tb00227.x

PENNER, G. A. 1996. RAPD analysis of plant genomes, Jauhar P.P., ed., Methods of Genome Analysis in Plants, CRC, Boca Raton, 251-268.

REITER, R. 2001. PCR based marker system in DNA based marker in plants, Second Edition, Kluwar Academic Publishers, 9-29. http://dx.doi.org/10.1007/978-94-015-9815-6 2

TOMAR RUKAM, S., PARAKHIA, M. V., KAVANI, R. H., DOBARIYA, K L. THAKKAR, J. R., RATHOD, V. M. DHINGANI, R. M and GOLAKIYA, B. A. 2014. Characterization of castor (Ricinus communis L.) genotypes using different markers. Res. J. Biotech, 9 (2), 6-13.

VIENNE, D., SANTONI, S. and FALQUE M. 2003. Principal Sources of Molecular Markers. Molecular Markers in Plant Genetics and Biotechnology, Vienne D.D., ed., Science Publishers Inc., Plymouth, UK, 3-41.

WEBER, J. L. 1990. Informativeveness of human (dC-dA)n x (dG-dT)n polymorphism. Genomics, 7, 524-530. http://dx.doi.org/10.1016/08887543(90)90195-Z

WEIR, B.S. 1990. Genetic data analysis. Sinauer Associated, Sunderland, Mass.

WELSH, J. and MCCLELLAND, M., 1990. Fingerprinting genomes using PCR with arbitrary primers, Nucleic Acids Research, 18, 7213-7218 http://dx.doi.org/10.1093/nar/18.24.7213 